\title{
Om in God te glo
}

Book title:

Die Christen-ateïs: Om in God te glo, maar te leef asof Hy

nie bestaan nie

\section{Book cover:}

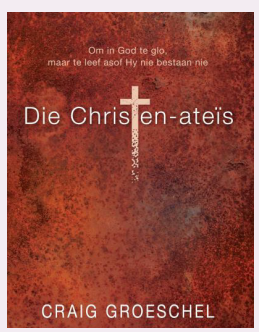

Author:

C. Groeschel

ISBN:

978-1-77000-867-0

Publisher:

Christelike

Uitgewersmaatskappy, 2012,

R109.95

*Book price at time of review

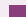

Review title :

Om in God te glo

Reviewer:

Pieter H. Heystek ${ }^{1}$

Affiliation:

${ }^{1}$ Reformed Church, Pretoria-

Montanapoort

Email:

drpieter@montanapoort.co.za

Postal address:

PO Box 1697, Montanapark

0159, South Africa

How to cite this book review: Heystek, P.H., 2013, 'Om in

God te glo', In die Skriflig/

In Luce Verbi 47(1), Art.

\#655, 1 page. http://dx.doi.

org/10.4102/ids.v47i1.655

\section{Copyright:}

C 2013. The Authors.

Licensee: AOSIS

OpenJournals. This work

is licensed under the

Creative Commons

Attribution License.

\section{Read online:}

Met Titus 1:16 as uitgangspunt slaag die outeur daarin om die saak van om in God te glo, maar te leef asof Hy nie bestaan nie, aan te spreek én 'n appèl op die leser se gewete te maak. Skynheiligheid is inderdaad vir elke kind van die Here nie bloot 'n moontlikheid nie, maar inderdaad ' $n$ werklikheid. Groeschel stel homself in die inleiding van die boek bekend as 'n 'Christen-ateïs' en stel dit duidelik dat sy boek bedoel is vir 'elkeen wat genoeg moed het om te erken dat hulle skynheilig is ... ' Sy gebed is dat elke leser 'n stuk skynheiligheid sou kon afskud en 'n lewe sal leef wat Christus werklik verheerlik.

In twaalf hoofstukke word die tema van skynheiligheid aangespreek en wat die leser laat besef hoe tersake die moontlikheid is om die lewende Here nie in kinderlike eerlikheid en opregtheid te dien nie. Om die leser te motiveer om hierdie boek te lees, word die inhoudsopgawe hier vermeld:

Wanneer jy in God glo,

- maar Hom nie regtig ken nie

- maar skaam is oor jou verlede

- maar nie seker is of Hy jou liefhet nie

- maar nie aan gebed glo nie

- maar nie dink Hy is regverdig nie

- maar nie wil vergewe nie

- maar nie dink jy kan verander nie

- maar jou steeds heeltyd bekommer

- maar geluk ten alle koste najaag

- maar meer op geld vertrou

- maar nie jou geloof deel nie

- maar nie aan Sy kerk glo nie

Die meriete van die boek bestaan daarin dat die outeur daarin slaag om vanuit sy eie ervaring die onderwerp van 'Christen-ateïsme' te verwoord. Hierdie boek bied geen spekulasie nie, maar is 'n eerlike belewenis van persoonlike ervarings.

Die Christen-ateïs is 'n lekker lees boek wat deur enige kind van die Here behoort gelees te word wat erns met sy of haar verhouding met die Here wil maak, Die outeur het 'n gemaklike skryfstyl en sy voorbeelde uit die alledaagse lewe lei daartoe dat die lesers gemotiveer word om die boek nie sommer neer te sit nie. Gepaste Skrifverwysings verhoog die standaard van die boek, gepaardgaande met die deurgaans prinsipiële uitgangspunte en kinderlik-korrekte standpunte van die outeur wanneer hy sy eie hart blootlê.

Hierdie boek word van harte aanbeveel as 'n populêr-wetenskaplike publikasie. 